\title{
Kajian Penggunaan Antihipertensi pada Pasien Strok di Instalasi Rawat Inap RSU Anutapura Palu Tahun 2017
}

\author{
Joni Tandi, Dian S. Waruwu, Ayu Martina \\ Program Studi Farmasi, STIFA Pelita Mas Palu, Palu, Indonesia
}

\begin{abstract}
Abstrak
Strok adalah gangguan serebrovaskular yang sering menyebabkan kerusakan yang luas dan jangka panjang pada kesehatan pasien. Hipertensi merupakan faktor risiko terpenting untuk strok. Pengobatan hipertensi tidak dilakukan dalam jangka pendek, oleh sebab itu, dibutuhkan perhatian khusus untuk penatalaksanaannya. Penelitian ini bertujuan untuk mengkaji jenis maupun golongan obat antihipertensi yang digunakan pada pasien strok dalam hubungannya dengan potensi terjadinya drug related problems (DRPs) terkait pemilihan obat dan dosis antihipertensi. Penelitian ini merupakan penelitian deskriptif dengan pengumpulan data secara prospektif pada periode September-Desember tahun 2017 yang didasarkan pada catatan rekam medis pasien strok di instalasi rawat inap RSU Anutapura Palu. Teknik pengambilan sampel dilakukan secara purposive sampling yang memenuhi kriteria inklusi. Hasil penelitian terhadap 32 pasien strok menunjukkan penggunaan jenis dan golongan antihipertensi terbanyak yaitu amlodipin yang termasuk golongan calcium channel blocker (CCB) sebanyak 28 pasien $(56 \%)$, captopril yang termasuk golongan angiotensin converting enzyme inhibitor sebanyak 6 pasien $(12 \%)$, candesartan yang termasuk golongan angiotensin receptor blocker sebanyak 5 pasien $(10 \%)$, nikardipin sebanyak 3 pasien (6\%) dan diltiazem sebanyak 4 pasien (8\%) yang termasuk golongan CCB. Adapun DRPs yang ditemukan terkait pemilihan obat dan dosis antihipertensi pada pasien strok yaitu adanya obat antihipertensi yang tidak tepat sebanyak 6 pasien $(18,75 \%)$ dan adanya dosis terlalu tinggi sebanyak 9 pasien $(28,12 \%)$. Diharapkan apoteker dapat berperan dalam mengidentifikasi adanya kemungkinan DRPs penggunaan antihipertensi pada pasien strok untuk meminimalkan persentase kejadian.
\end{abstract}

Kata kunci: Antihipertensi, drug related problems (DRPs), hipertensi, strok

\section{Study of Antihypertensive Use in Stroke Patients at Inpatient Installation of Anutapura General Hospital Palu in 2017}

\begin{abstract}
Stroke is a cerebrovascular disorder that often causes extensive and long-term damage to the patient's health. Hypertension is the most important risk factor for stroke. Treatment of hypertension is not done in the short term, therefore special attention is needed for its management. This study aimed to examine the types and classes of antihypertensive drugs used in stroke patients in relation to the potential occurrence of drug related problems (DRPs) related to drug selection and antihypertensive doses. This research was a descriptive research with prospective data collected from September-December 2017 based on the medical record of stroke patient at inpatient installation of Anutapura General Hospital Palu. Sampling was done by purposive sampling technique which fulfilled the inclusion criteria. The results of the study of 32 stroke patients showed that the highest use of antihypertensive type and class are amlodipine as many as 28 patients (56\%) with class of calcium channel blocker (CCB), captopril 6 patients (12\%) with class of angiotensin-converting enzyme inhibitor, candesartan 5 patients $(10 \%)$ with class of angiotensin receptor blocker, nicardipin 3 patients $(6 \%)$ and diltiazem 4 patients $(8 \%)$ with class of CCB. The DRPs that were found to be related to drug selection and antihypertensive doses in stroke patients were due to the presence of inappropriate antihypertensive drugs found in 6 patients $(18.75 \%)$ and the number of high doses in 9 patients $(28.12 \%)$. The role of pharmacists is intended for identifying the possibility of DRPs for antihypertension in stroke patients to minimize the percentage of events.
\end{abstract}

Keywords: Antihypertensive, drug related problems (DRPs), hypertension, stroke

Korespondensi: Dr. Joni Tandi, Program Studi Farmasi, STIFA Pelita Mas Palu, Palu, Sulawesi Tengah 94111, Indonesia, email: jonitandi757@yahoo.com

Naskah diterima: 30 Mei 2018, Diterima untuk diterbitkan: 2 September 2018, Diterbitkan: 1 Desember 2018 


\section{Pendahuluan}

Strok merupakan penyebab kematian umum ketiga di negara-negara industri dan menjadi beban besar dengan meningkatnya dampak klinis, ekonomi dan sosial. ${ }^{1}$ Strok termasuk masalah yang berkembang dari perawatan kesehatan global disebabkan perkembangan demografi dengan peningkatan populasi lansia. Mortalitas strok telah menurun pada kurun waktu 20 tahun terakhir karena manajemen yang lebih baik dari faktor risiko dan indikator risiko (misalnya penyakit kardiovaskular). Namun, morbiditas strok terus meningkat akibat terjadinya peningkatan fibrilasi artial dan degenerasi neurovaskular yang terkait usia, misalnya perdarahan intrakranial angiopati serebral yang erat kaitannya dengan penyakit strok itu sendiri. ${ }^{1}$

Strok adalah gangguan serebrovaskular yang paling umum setelah penyakit jantung, dan menewaskan sekitar 5,7 juta orang setiap tahun di seluruh dunia. Ada dua jenis utama penyakit strok, yang paling umum adalah strok iskemik yang disebabkan oleh bekuan yang menyempit atau pemblokiran pembuluh darah (dengan prevalensi sekitar 80\%) diikuti oleh strok hemoragik yang disebabkan oleh perdarahan dari pembuluh darah di otak atau di ruang subarachnoid (sekitar 20\%). Keadaan pasien yang mengalami strok dan masih bertahan hidup dapat menjadi lebih buruk akibat kecacatan berat apabila dibandingkan pasien yang meninggal akibat strok. Hanya sekitar $40 \%$ dari pasien yang mengalami strok menerima perawatan medis terbaik setelah onset akut di Unit Strok dan Pusat Strok Komprehensif sehingga memperoleh pemulihan penuh dan bersifat indipendensi. Strok seringkali mengakibatkan kerusakan yang luas dan jangka panjang pada kesehatan pasien yang dapat menyebabkan kelemahan, kelumpuhan atau gangguan fungsi kognitif termasuk demensia vaskular, sehingga dari gambaran tersebut diperkirakan sekitar 5 juta orang di dunia cacat secara permanen akibat strok. $^{1}$

Salah satu faktor risiko tertinggi strok adalah hipertensi, lebih dari dua pertiga pasien yang menderita strok pertama mengalami peningkatan tekanan darah $(>130 / 80 \mathrm{mmHg})$. Diperkirakan sebanyak $80 \%$ dari beban strok disebabkan oleh hipertensi dan berbagai titik akhir kardiovaskular terjadi pada kelompok sosial rendah dan menengah, serta lebih dari $50 \%$ terjadi pada pasien berusia $>45$ tahun. ${ }^{1}$ Beberapa penelitian terdahulu menunjukkan manfaat dari mengontrol tekanan darah pada semua kelompok umur dan seluruh derajat hipertensi. Penurunan tekanan darah berperan penting dalam upaya meminimalkan risiko strok yang terkait dengan tekanan darah $<130$ $180 \mathrm{mmHg}{ }^{1}$

Pengobatan hipertensi membutuhkan waktu beberapa tahun, atau bahkan seumur hidup, dengan tetap mengontrol tekanan darah secara teratur. Pada sebagian kecil kasus, penderita hipertensi secara bertahap mungkin saja dapat menghentikan penggunaan obat. Namun, jika dibiarkan, hal tersebut akan menyebabkan risiko terjadinya komplikasi parah seperti serangan jantung, sehingga tekanan darah menjadi sulit dikontrol dan pada akhirnya dapat memicu penggunaan obat antihipertensi lebih banyak, serta memengaruhi terjadinya permasalahan terkait obat atau drug related problems (DRPs) dalam pelayanan farmasi klinik. ${ }^{2}$

Penelitian sebelumnya di Rumah Sakit X di Daerah Istimewa Yogyakarta menunjukkan bahwa kejadian DRPs pada pasien strok yang menjalani rawat inap diketahui terdapat ketidaktepatan dosis sebesar 13,2\%, indikasi tanpa terapi $75,5 \%$, obat tanpa indikasi $66 \%$ dan ketidakpatuhan tenaga profesional terhadap kesesuaian guideline sebesar 93,4\%. ${ }^{3}$ Penelitian yang dilakukan di Rumah Sakit Umum (RSU) Dr. Saiful Anwar Malang mengenai studi penggunaan calcium channel blocker (CCB) pada pasien strok hemoragik menunjukkan bahwa terdapat 54 sampel yang menggunakan 
CCB, antara lain nikardipin $64 \%$, nimodipin $12 \%$, amlodipin $2 \%$, serta diltiazem $6 \%{ }^{4}$ Penelitian lainnya yang menganalisis ketaatan pasien terhadap penggunaan statin dan terapi antihipertensi sebagai suatu faktor risiko strok fatal, dengan menggunakan regresi logistik biner dan multinomial untuk menganalisis hubungan tahun ke tahun mengenai kepatuhan pasien terhadap terapi statin dan antihipertensi menunjukkan hasil bahwa individu dengan hiperkolesterolemia dan hipertensi yang gagal mengambil statin yang diresepkan dan obat antihipertensi mengalami peningkatan risiko strok fatal secara substansial. Risikonya lebih rendah jika pasien patuh pada salah satu dari terapi ini. ${ }^{5}$

Berdasarkan data survei awal terhadap pasien strok yang bersumber dari data rekam medik RSU Anutapura Palu, total pasien strok pada 3 tahun berturut-turut yaitu pada tahun 2015 total pasien strok sebanyak 503 dan pasien meninggal sebanyak 50 pasien, tahun 2016 dengan total pasien strok sebanyak 611 dan pasien meninggal sebanyak 126 pasien, dan tahun 2017 di periode Januari-Juni 2017 dengan total pasien strok yaitu sebanyak 295 dan pasien meninggal sebanyak 71 pasien. Data tersebut menunjukkan jumlah pasien strok meningkat tiap tahunnya dan beberapa penelitian sebelumnya menunjukkan terdapat hubungan antara jenis terapi antihipertensi dan penurunan tekanan darah pada pasien strok. Oleh karena itu, berdasarkan hal tersebut, peneliti tertarik untuk melakukan penelitian yang bertujuan untuk mengetahui gambaran dari penggunaan obat antihipertensi meliputi jenis obat dan golongan obat antihipertensi yang sering digunakan pada pasien strok, dan untuk mengetahui adanya kejadian DRPs terkait pemilihan obat kategori penggunaan obat antihipertensi yang tidak tepat, obat antihipertensi tanpa indikasi dan pemilihan dosis kategori penggunaan obat antihipertensi dosis terlalu tinggi, dosis terlalu rendah dan frekuensi tidak cukup pada pasien strok di
Instalasi Rawat Inap RSU Anutapura Palu. Dari tujuan tersebut, maka hipotesis penelitian mengenai golongan obat antihipertensi yang sering digunakan pada pasien strok di RSU Anutaparu adalah golongan diuretik, golongan angiotensin converting enzyme inhibitors (ACEIs) dan golongan CCB, sedangkan hipotesis terkait kejadian DRPs yaitu adanya kejadian DRPs terkait pemilihan obat kategori penggunaan obat antihipertensi yang tidak tepat, obat antihipertensi tanpa indikasi serta pemilihan dosis kategori penggunaan obat antihipertensi dosis terlalu tinggi, dosis terlalu rendah dan frekuensi tidak cukup pada pasien strok di Instalasi Rawat Inap RSU Anutaparu Palu.

\section{Metode}

Populasi dan sampel

Populasi pada penelitian ini adalah semua pasien strok yang sedang menjalani rawat inap di RSU Anutapura Palu. Sampel adalah pasien penyakit strok yang diberikan terapi pengobatan antihipertensi dan memenuhi kriteria inklusi selama penelitian berlangsung sesuai periode waktu yang telah ditetapkan. Pengambilan sampel dilakukan menggunakan metode purposive sampling. Kriteria inklusi yaitu antara lain: (a) Pasien rawat inap dengan diagnosis utama penyakit strok. (b) Pasien menjalani terapi pengobatan antihipertensi di instalasi rawat inap RSU Anutapura Palu pada bulan September sampai Desember tahun 2017. (c) Data rekam medik pasien yang lengkap memuat rincian diagnosis penyakit, rincian keluhan tambahan, riwayat penyakit pasien, data obat yang digunakan selama perawatan maupun riwayat obat sebelum perawatan dan data pemeriksaan fisik pasien (seperti data laboratorium atau CT Scan serta pemeriksaan pendukung lainnya). Kriteria eksklusi antara lain: (a) Pasien strok yang tidak bersedia untuk menjadi subjek penelitian. (b) Pasien strok yang dirawat kurang dari 1-2 hari baik yang diizinkan pulang, pulang paksa maupun 
meninggal. ${ }^{6}$

Waktu dan tempat penelitian

Penelitian dilaksanakan pada bulan September sampai dengan Desember tahun 2017 di ruang rawat inap murai atas RSU Anutapura Palu. Penelitian ini dilakukan setelah mendapat persetujuan penelitian dari Sekolah Tinggi Ilmu Farmasi (STIFA) Pelita Mas Palu dengan nomor surat 536/YPM-STIFA-PL/BAAK/IX/ 2017 dan persetujuan Direktur RSU Anutapura Palu dengan nomor surat 800.2/86.XII/Diklat/ RS. Penelitian dimulai dari pencatatan jumlah pasien strok rawat inap yang mendapatkan terapi antihipertensi, pencatatan data pasien strok diperoleh dari proses observasi di RSU Anutapura Palu.

Prosedur penelitian

Pengambilan sampel menggunakan teknik metode purposive sampling. Data diambil dari bagian ruang rawat inap penyakit dalam dan bagian instalasi farmasi RSU Anutapura Palu mengenai penggunaan obat-obat antihipertensi untuk mengetahui jenis dan golongan obat antihipertensi terkait kemungkinan kejadian DRPs. Data yang diperoleh lalu dikumpulkan dan dianalisis secara deskriptif.

Analisis data

Analisis data yang digunakan yaitu analisis deskriptif yang dilakukan pada tiap variabel untuk mengetahui adanya kejadian DRPs terkait penggunaan antihipertensi pada pasien strok di instalasi rawat inap RSU Anutapura Palu. Data yang dianalisis berupa: (1) Data terkait pasien berupa umur, jenis kelamin, diagnosis penyakit, penyakit penyerta dan lama perawatan yang diperoleh melalui rekam medis pasien. (2) Data mengenai penggunaan obat antihipertensi pada pasien strok meliputi pemilihan obat dan dosis antihipertensi, untuk mengkaji adanya kemungkinan DRPs dengan cara melakukan perbandingan hasil terhadap standar acuan berdasarkan literatur guideline
Perdossi tahun 2011, Standar Pelayanan Minimal (SPM) RSU Anutapura Palu, JNC 8, ISO Farmakoterapi tahun 2008, Informasi Spesialite Obat Volume 51 tahun 2017 sampai dengan 2018 dan Medscape.

\section{Hasil}

Karakteristik subjek penelitian

Berdasarkan data yang diperoleh, diketahui bahwa pasien penderita strok yang menjalani perawatan di ruang rawat inap murai atas RSU berdasarkan jenis kelaminnya lebih banyak terjadi pada pasien laki-laki dibandingkan perempuan; pada laki-laki sebanyak 22 pasien $(68,75 \%)$ dan perempuan sebanyak 10 pasien $(31,25 \%)$. Data usia pasien strok dibagi ke dalam 4 kelompok, yaitu usia 36 -45 tahun sebanyak 2 orang $(6,25 \%)$, usia $46-55$ tahun sebanyak 6 orang $(18,75 \%)$, usia 55-65 tahun sebanyak 15 orang $(46,88 \%)$, serta usia $>65$ tahun sebanyak 9 orang $(28,12 \%)$. Dari data yang diperoleh, strok lebih banyak terjadi pada pasien yang berusia 55-65 tahun.

\section{Karakteristik klinis}

Data yang didapatkan mengenai klasifikasi strok pada pasien rawat inap adalah pasien strok hemoragik sebanyak 6 orang $(18,75 \%)$, pasien strok iskemik yaitu sebanyak 19 orang $(59,37 \%)$ dan pasien yang mengalami strok namun tidak menyebut keduanya sebanyak 7 orang $(21,88 \%)$. Jumlah penderita strok berdasarkan riwayat penyakit hipertensi yaitu pasien dengan riwayat hipertensi sebanyak 21 orang $(65,62 \%)$ dan pasien strok tanpa riwayat penyakit hipertensi sebanyak 11 orang (34,38\%).

Diperoleh hasil bahwa jenis antihipertensi yang paling banyak digunakan oleh pasien strok di instalasi rawat inap yaitu amlodipin (28 pasien, 56\%), dengan neurosanbe sebagai jenis obat pendamping terbanyak (27 pasien, 20,76\%) (Gambar 1 dan 2). Jenis cairan yang paling banyak digunakan adalah ringer laktat 


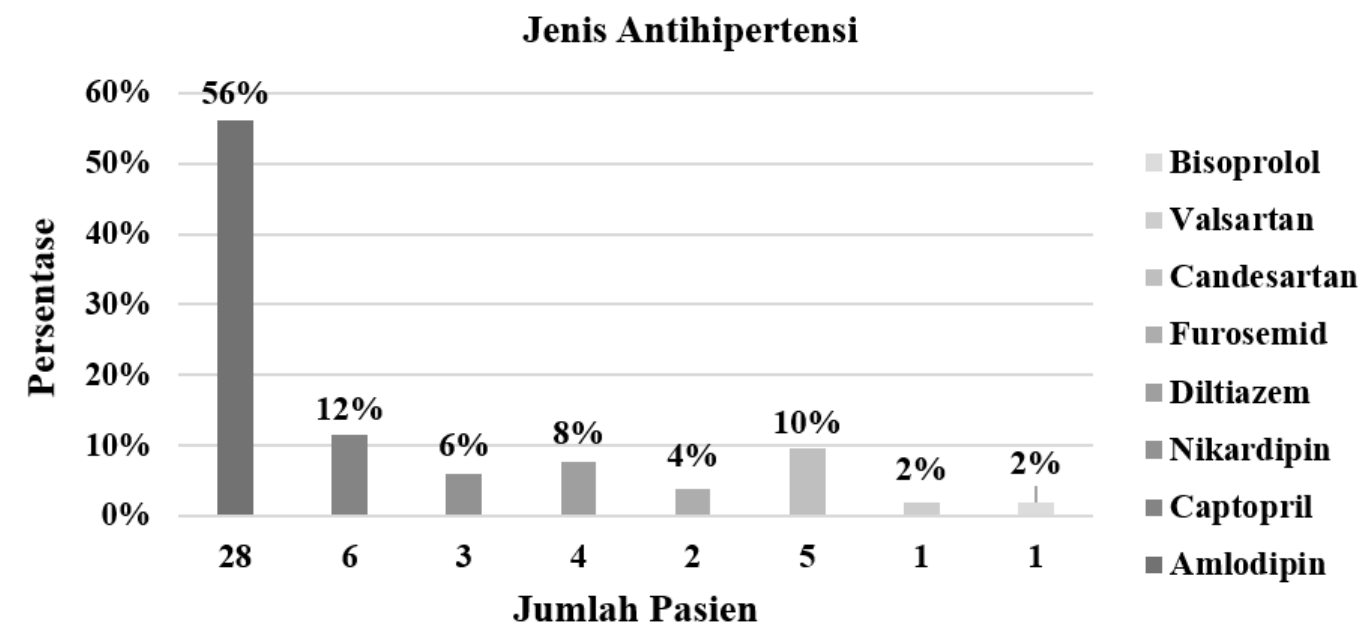

Gambar 1 Persentase Pasien Strok Berdasarkan Jenis Antihipertensi yang Digunakan pada Pasien Strok di Instalasi Rawat Inap RSU Anutapura Palu Tahun 2017

(31 pasien, 65,96\%) yang dapat dilihat pada Gambar 3. Selain itu, dari hasil penelitian ini ditemukan DRPs terkait pemilihan obat dan dosis antihipertensi, yaitu obat tidak tepat dengan persentase sebesar $18,75 \%$ dan dosis terlalu tinggi sebesar 28,12\% (Gambar 4).

\section{Pembahasan}

Berdasarkan data yang diperoleh mengenai terapi antihipertensi yang diberikan kepada pasien strok di instalasi rawat inap ruangan murai atas RSU Anutapura Palu, diketahui bahwa lima jenis obat di antaranya adalah antihipertensi dengan persentase penggunaan tertinggi, antara lain amlodipin, kaptopril, kandesartan, nikardipin dan diltiazem. Tingginya persentase penggunaan amlodipin disebabkan amlodipin berguna untuk mencegah strok tipe aterotrombotik pada arteri besar di otak, hal ini didukung oleh penelitian sebelumnya yang membuktikan bahwa amlodipine dapat menurunkan kejadian strok 23\% lebih besar bila dibandingkan dengan atenolol. ${ }^{7}$ Selanjutnya, persentase penggunaan kaptopril dipengaruhi oleh fakta bahwa kaptopril merupakan salah

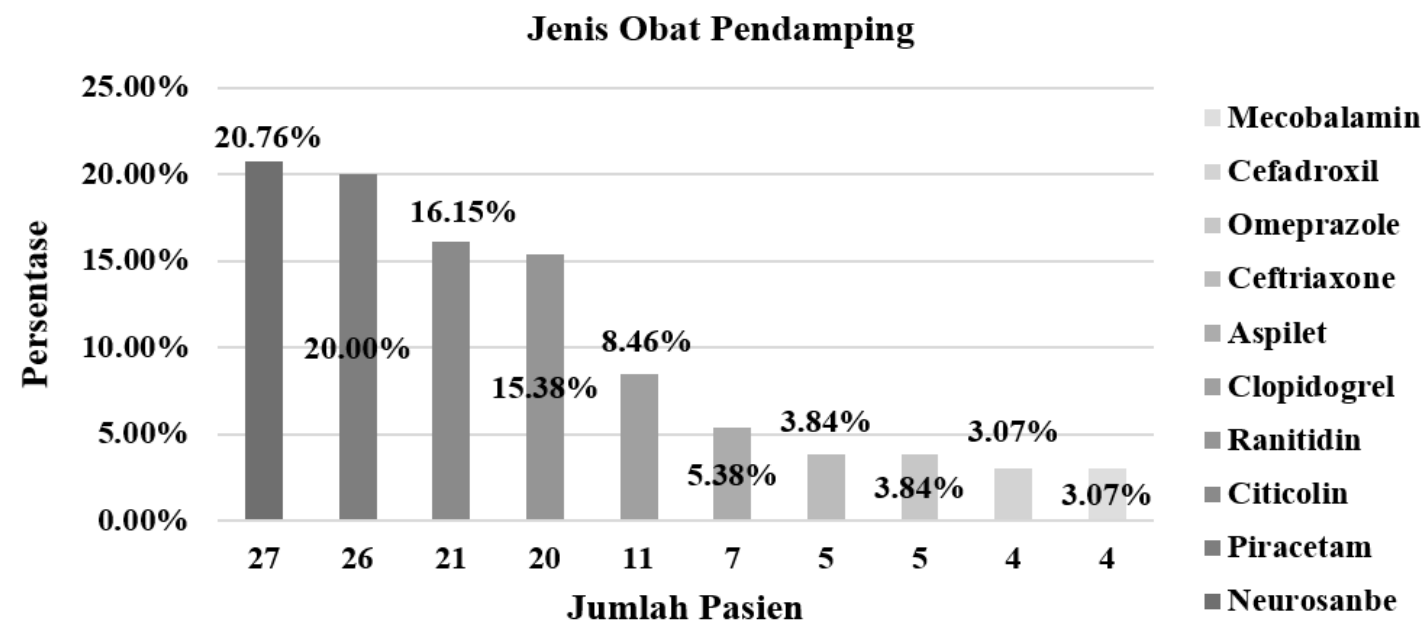

Gambar 2 Persentase Pasien Strok Berdasarkan Jenis Obat Pendamping yang Digunakan pada Pasien Strok di Instalasi Rawat Inap RSU Anutapura Palu Tahun 2017 


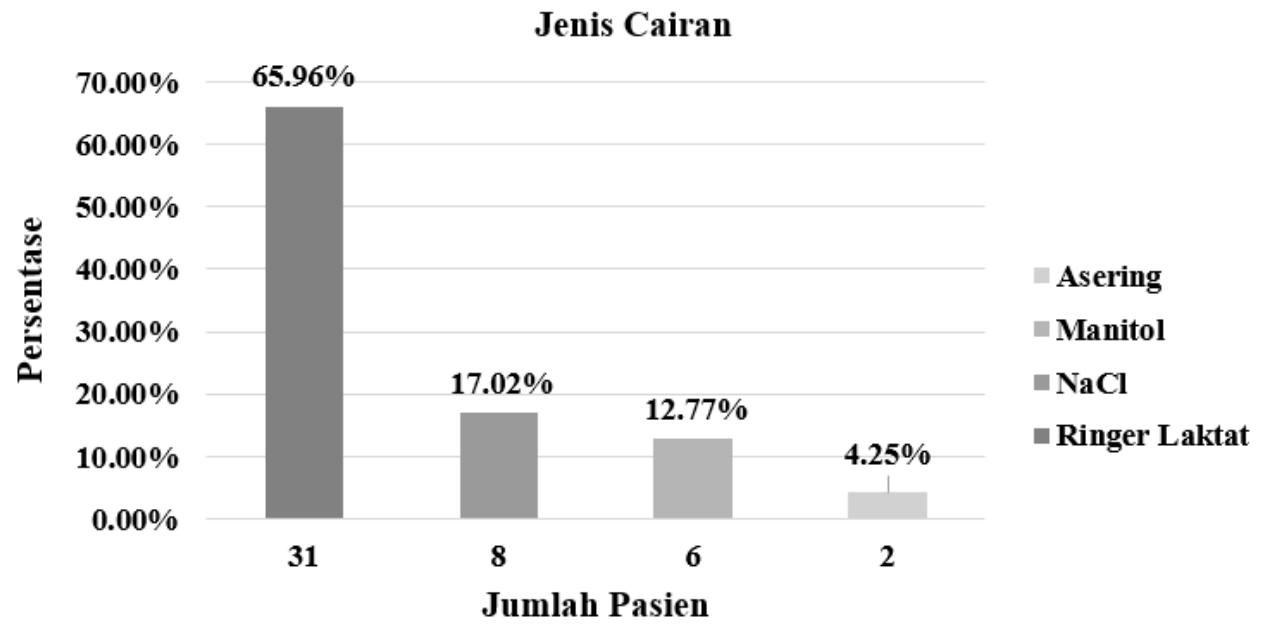

Gambar 3 Persentase Pasien Strok Berdasarkan Jenis Cairan yang Digunakan pada Pasien Strok di Instalasi Rawat Inap RSU Anutapura Palu Tahun 2017

satu jenis antihipertensi golongan ACEI yang berguna sebagai prediktor independen untuk kelangsungan hidup setelah serangan strok iskemik, atau dengan kata lain antihipertensi dalam golongan ACEI dapat digunakan untuk profilaksis strok iskemik berulang. ${ }^{8}$ Tingginya persentase penggunaan kandesartan dapat dipengaruhi oleh fakta bahwa kandesartan adalah penghambat reseptor angiotensin II tipe 1 (ARB) yang telah terbukti membatasi strok iskemik dan memperbaiki hasil strok. Pada penelitian sebelumnya mengenai strok, kandesartan menginduksi efek proangiogenik yang disebabkan oleh faktor pertumbuhan endotel vaskular yang berfungsi menciptakan pembuluh darah baru setelah cedera. ${ }^{9}$ Persentase penggunaan terapi antihipertensi diltiazem dan nikardipin lebih rendah dibandingkan lainnya karena penggunaan kedua obat ini hanya dalam keadaan darurat.

Berdasarkan data yang diperoleh mengenai sepuluh jenis obat pendamping yang paling banyak digunakan, diketahui bahwa lima jenis obat pendamping di antaranya merupakan obat

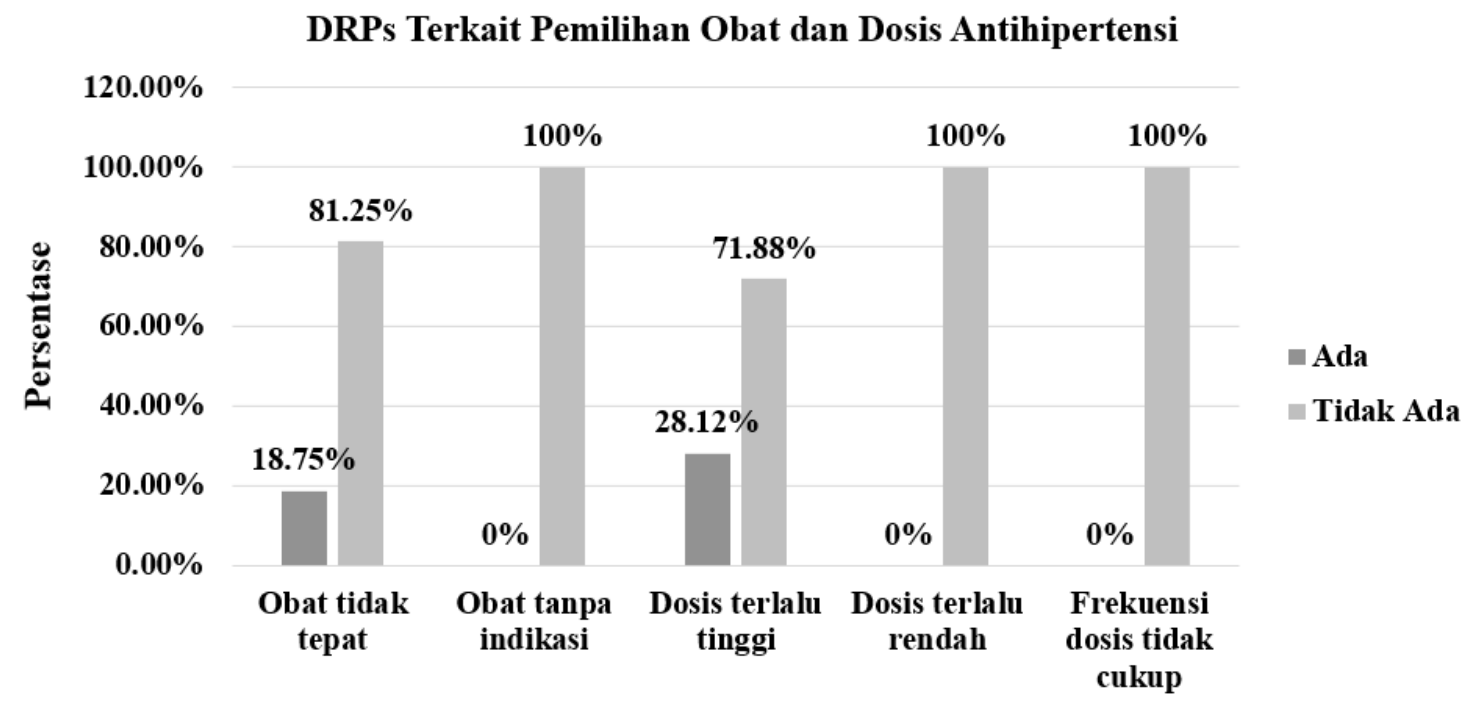

Gambar 4 Persentase Drug Related Problems (DRPs) Terkait Pemilihan Obat dan Dosis Antihipertensi pada Pasien Strok di Instalasi Rawat Inap RSU Anutapura Palu Tahun 2017 
pendamping dengan persentase tertinggi yaitu neurosanbe, pirasetam, sitikolin, ranitidin dan klopidogrel. Tingginya persentase dari penggunaan obat pendamping neurosanbe pada pasien strok dipengaruhi oleh sebab neurosanbe merupakan gabungan dari B1, B6 dan B12 yang sangat baik untuk mengatasi gangguan kesehatan saraf pada pasien strok dan diketahui pula bahwa strok merupakan penyebab penting masalah kognitif seperti dementia, maka penggunaan neurosanbe juga dikaitkan untuk mengatasi hal tersebut. ${ }^{10,11}$ Selanjutnya, persentase dari penggunaan obat pirasetam pada pasien strok dipengaruhi oleh fakta bahwa pirasetam dapat mengatasi gangguan peredaran darah otak pascatrauma pada pasien strok dan penelitian sebelumnya yang menunjukkan bahwa pasien dengan strok iskemik yang menggunakan piracetam menunjukkan adanya fungsi neurologi dilihat berdasarkan parameter Glasglow Coma Scale (GCS) yang berupa respon mata, respon verbal dan respon motorik. ${ }^{12}$ Selanjutnya, persentase penggunaan sitikolin pada pasien strok dipengaruhi oleh fakta bahwa sitikolin merupakan neuroprotektor yang mempunyai evidence based terbaik dalam peningkatan fungsi neurologi dan kognitif pasca serangan strok, juga berdasarkan hasil dari penelitian sebelumnya yang memperoleh hasil bahwa, pada dosis $1000 \mathrm{mg}$, pasien strok iskemik baik pada strok berulang maupun tidak berulang memberikan nilai GCS tertinggi. ${ }^{13}$ Selanjutnya, persentase dari penggunaan obat ranitidin pada pasien strok dipengaruhi oleh sebab ranitidin dapat mengatasi tukak lambung pada pasien strok yang dapat diakibatkan stres dan berbagai faktor lainnya. Selanjutnya, persentase dari penggunaan klopidogrel pada pasien strok dikaitkan dengan penelitian sebelumnya yang menunjukkan hasil bahwa penambahan klopidogrel ke aspirin telah terbukti mengurangi risiko strok di antara pasien strok dengan atrial fibrillation dan mereka dengan sindrom koroner akut namun penggunaan keduanya sebagai antiplatelet ganda meningkatkan pendarahan. ${ }^{14}$ Adapun penggunaan obat pendamping ini pada pasien strok disesuaikan kembali dengan kebutuhan dan kondisi pasien.

Berdasarkan data tentang jenis cairan yang diberikan pada pasien strok di instalasi rawat inap ruangan murai atas RSU Anutapura Palu, dapat diketahui bahwa penggunaan cairan dengan persentase tertinggi yaitu ringer laktat yang disebabkan ringer laktat mengandung beberapa elektrolit yang dibutuhkan pasien strok seperti ion natrium $130 \mathrm{mmol} / \mathrm{l}$, klorida $111 \mathrm{mmol} / \mathrm{l}$, kalium 4,0 mmol/1, kalsium 2,7 $\mathrm{mmol} / \mathrm{l}$ dan buffer $29 \mathrm{mmol} / \mathrm{l}$, yang mirip dengan cairan plasma tubuh. ${ }^{15}$ Ringer laktat digunakan sebagai larutan rumatan untuk memelihara homeostasis elektrolit, khususnya kalium dan natrium setelah fase akut strok. Tingginya persentase dari penggunaan cairan $\mathrm{NaCl}$ pada pasien strok disebabkan beberapa obat antihipertensi yang digunakan pada pasien strok dilarutkan di dalam cairan $\mathrm{NaCl}$ seperti nikardipin. Selanjutnya, persentase penggunaan manitol terhadap pasien strok dapat dipengaruhi oleh sebab penggunaannya sebagai diuretik untuk mengurangi Tekanan Intra Kranial (TIK), massa pada otak dan Tekanan Intra Okular (TIO) yang tinggi yang dapat disebabkan oleh beberapa keadaan, seperti komplikasi akibat cedera kepala yang menyebabkan pembendungan cairan di otak. Manitol dapat menginduksi diuresis osmotik, sehingga membantu mencegah peningkatan status volume intravaskular. Pada penelitian yang telah dilakukan sebelumnya, ditunjukkan bahwa manitol secara aman dan efektif dapat mempertahankan variasi volume strok tinggi sebesar 10-20\% untuk mengurangi kehilangan darah selama donor hepatektomi hidup. ${ }^{16}$ Selanjutnya, persentase penggunaan cairan asering lebih rendah dibandingkan dengan yang lainnya disebabkan asetat dalam larutan asering lebih banyak dimetabolisme dalam otot dan sebagian kecil dalam ginjal 
dan jantung, dalam hal ini pada pasien strok cenderung mengalami atrofi otot berbeda dengan laktat yang dimetabolisme di dalam hati. Selain itu, asering dapat berinteraksi dengan obat lain yang digunakan pada pasien strok seperti aspirin pada dosis 80-100 mg digunakan sebagai antikoagulan pada pasien strok.

Berdasarkan data mengenai ketepatan penggunaan obat antihipertensi berdasarkan ketetapan standar dan kriteria yang berkaitan dengan pemilihan jenis maupun golongan antihipertensi, diperoleh hasil penggunaan antihipertensi pada pasien strok di instalasi rawat inap ruangan murai atas RSU Anutapura Palu tahun 2017 yang masuk dalam kategori tepat obat sebanyak 26 pasien $(81,25 \%)$ dan tidak tepat obat sebanyak 6 pasien $(18,75 \%)$. Adapun ketidaktepatan pemilihan obat yang dimaksud adalah penggunaan obat amlodipin pada pasien strok pendarahan, dalam hal ini, obat yang dianjurkan berdasarkan literatur dan standar acuan adalah nimodipin. Penggunaan amlodipin dibandingkan dengan nimodipin ini dilakukan dengan landasan menghindari efek samping seperti yang dihasilkan oleh obat antihipertensi lain, dan juga berdasarkan hasil penelitian bahwa amlodipin adalah jenis obat antihipertensi yang sering diresepkan untuk pasien strok. Selain itu, penggunaan amlodipin ini juga dilandasi oleh fakta bahwa efek dari terapi amlodipin tidak langsung menyebabkan hipotensi pada pasien strok yang tekanan darahnya harus diperhatikan. Obat nimodipin juga diberikan pada pasien strok di instalasi rawat inap ruangan murai atas RSU Anutapura Palu, namun hanya pada kondisi kritis seperti di ruang ICU, dan biasanya pada pasien strok hemoragik yang kehilangan kesadaran. Standar acuan dari ketidaktepatan obat antihipertensi yang diberikan yaitu Guideline Perdossi 2011, JNC 8, ISO Farmakoterapi dan Standar Pelayanan Medis RSU Anutapura Palu.

Data penggunaan obat antihipertensi tanpa indikasi menunjukkan bahwa penggunaan antihipertensi pada pasien strok memperoleh hasil yaitu $100 \%$ obat yang diberikan telah sesuai indikasi, dalam hal ini, terdapat gejala hipertensi yang memperburuk kondisi klinis pasien yang ditandai dengan peningkatan tekanan darah di atas normal. Hal ini sesuai dengan literatur Informasi Spesialite Obat (ISO) Volume 51.

Berdasarkan data yang diperoleh mengenai penggunaan dosis obat antihipertensi yang terlalu tinggi yang dapat menyebabkan efek yang tidak dikehendaki, seperti toksisitas, diperoleh hasil terdapat 23 pasien $(71,88 \%)$ yang menerima obat antihipertensi dengan dosis yang telah sesuai, dan terdapat 9 pasien $(28,12 \%)$ yang menerima obat antihipertensi dengan dosis yang terlalu tinggi. Penggunaan dosis yang terlalu tinggi pada pasien strok yaitu pada penggunaan amlodipin, dalam hal ini dosis awal yang dianjurkan untuk pasien lansia yaitu $1 \times 2,5 \mathrm{mg}$, namun penggunaan dosis amlodipin yang diberikan pada pasien strok di instalasi rawat inap murai yaitu 5-10 mg untuk pasien lansia. Penggunaan dosis ini dinilai tinggi bagi pasien lansia melalui studi literatur yang dilakukan, serta tidak adanya keterangan pada rekam medis bahwa pasien tersebut memiliki riwayat penyakit hipertensi sebelumnya. Adapun yang menjadi landasan penggunaan amlodipin dengan dosis 5-10 mg sehari di instalasi rawat inap murai ini adalah kondisi pasien dengan tekanan darah yang abnormal, yang dalam hal ini, tekanan darah pada pasien dapat meningkat kapan saja karena berbagai faktor. Standar acuan yang digunakan dalam penentuan dosis dari obat antihipertensi yaitu Medscape dan ISO Volume 51.

Berdasarkan data yang diperoleh mengenai penggunaan dosis obat antihipertensi yang terlalu rendah sehingga efek yang diinginkan menjadi tidak tercapai, diperoleh hasil bahwa tidak ada penggunaan obat antihipertensi pada pasien strok dengan dosis yang terlalu 
rendah (100\%). Adapun standar acuan yang digunakan ialah Medscape. Lalu berdasarkan data yang diperoleh mengenai penggunaan antihipertensi dengan frekuensi dosis yang tidak cukup sehingga efek yang diinginkan tidak tercapai, dan mengacu pada Medscape dan buku ISO sebagai standar penentuan frekuensi regimen dosis, diperoleh hasil bahwa tidak ada penggunaan antihipertensi dengan frekuensi dosis yang tidak cukup (100\%).

Limitasi pada penelitian ini terletak dalam proses pengambilan data pasien strok yang disebabkan terbatasnya tempat dan waktu untuk melakukan pencatatan dan pengamatan lebih lanjut mengenai data pasien strok yang tertera pada rekam medik pasien. Selain itu, selama proses pengambilan data, tim peneliti tidak dapat secara leluasa mencatat data pasien sroke, sedangkan penelitian yang dilakukan merupakan suatu penelitian prospektif (follow up research), yang dalam hal ini peneliti diharuskan untuk melakukan pengamatan terhadap data peristiwa pasien yang belum dan akan terjadi. Hal ini disebabkan sumber data yang berasal dari rekam medis pasien tersebut biasanya digunakan secara bersamaan pada saat berlangsungnya pemeriksaan pasien setiap hari. Rekomendasi penanganan yang disarankan antara lain: (1) Disediakan tempat yang memadai serta waktu yang cukup bagi para peneliti untuk melakukan observasi secara lebih lanjut mengenai data pasien strok melalui status pasien dalam rekam medis. (2) Disediakan data pasien yang up to date yang ditujukan untuk tujuan khusus penelitian untuk memudahkan peneliti secara leluasa mencatat data penelitian terhadap pasien yang bersangkutan, khususnya jika penelitian yang dilakukan merupakan penelitian prospektif.

\section{Simpulan}

Jenis beserta golongan obat antihipertensi terbanyak yang diberikan pada pasien strok di instalasi rawat inap RSU Anutapura Palu tahun 2017 yaitu amlodipin yang termasuk golongan calcium channel blocker sebanyak 28 pasien $(56 \%)$, kaptopril yang termasuk ke dalam golongan angiotensin converting enzym inhibitor yaitu sebanyak 6 pasien (12\%), kandesartan yang termasuk dalam golongan angiotensin reseptor blocker yaitu sebanyak 5 pasien (10\%), nikardipin dan diltiazem yang termasuk golongan calcium channel blocker masing-masing yaitu sebanyak 3 pasien (6\%) dan sebanyak 4 pasien (8\%). Adapun Drug Related Problems (DRPs) terkait pemilihan obat antihipertensi pada pasien strok kategori adanya obat antihipertensi yang tidak tepat yaitu sebanyak 6 pasien (18,75\%), dan adanya penggunaan obat antihipertensi dengan dosis terlalu tinggi sebanyak 9 pasien $(28,12 \%)$, dan antihipertensi yang tidak cukup $0 \%$. Dari hasil tersebut, dapat dilihat bahwa kejadian DRPs terkait penggunaan antihipertensi pada pasien strok masih dapat ditangani dengan baik, namun tetap diperlukan perhatian untuk meminimalkan angka kejadian DRPs terkait penggunaan antihipertensi selanjutnya pada pasien strok.

\section{Ucapan Terima Kasih}

Ucapan terima kasih ditujukan kepada Kampus Sekolah Tinggi Ilmu Farmasi (STIFA) Pelita Mas Palu dan RSU Anutapura Palu atas izin dan kesempatan yang diberikan sehingga penulis dapat melakukan penelitan ini.

\section{Pendanaan}

Penelitian ini dilakukan tanpa didanai oleh sumber hibah manapun.

\section{Konflik Kepentingan}

Seluruh penulis menyatakan tidak terdapat potensi konflik kepentingan dengan penelitian, kepenulisan (authorship) dan publikasi artikel ini. 


\section{Daftar Pustaka}

1. Hennerici MG, Johannes B, Rolf K, Kristina S. Stroke. England: Oxford University Press; 2012.

2. Buckman R, Westcott P. What you really need to know about high blood pressure. New York: Lebhar-Friedman; 2000.

3. Nurhaini R, Akrom, Jatiningrum A. Drug related problems in patients with stroke: A retrospective study at hospital-X Yogyakarta. Cerata J Pharm Sci. 2017;8 (1):1-9.

4. Nadriatul U, Hasmono D, Lilik Y. Studi penggunaan calcium channel blocker (CCB) pada pasien stroke hemorraghic. Pharm Media. 2013;10(2):71-83.

5. Herttua K, Martikainen P, Batty GD, Kivimaki M. Poor adherence to statin and antihypertensive therapies as risk factors for fatal stroke. J Am Coll Cardiol. 2016; 67(13): 1507-15. doi: 10.1016/j.jacc.201 6.01 .044

6. Ruterlin V, Tandi J. Pengaruh pengobatan ARV terhadap peningkatan limfosit pasien HIV-AIDS di Rumah Sakit Pemerintah Kota Palu. Indones J Clin Pharm. 2014;3(1):36. doi: 10.15416/ijc p.2014.3.1.30

7. Ravenni R, Jabre JF, Casiglia E, Mazza A. Primary stroke prevention and hypertension treatment: Which is the first-line strategy? Neurol Int. 2011;3(2):e12. doi: 10.4081/n i.2011.e12.

8. Hassan Y, Aziz NA, Al-Jabi SW, Looi I, Zyoud SH. Impact of angiotensinconverting enzyme inhibitors administration prior to acute ischemic stroke onset on inhospital mortality. J Cardiovasc Pharmacol Ther. 2010;15(3): 274-81. doi: 10.1177/1 074248410373751

9. Alhusban A, Kozak A, Ergul A, Fagan SC. AT1 receptor antagonism is proangiogenic in the brain: BDNF a novel mediator. $\mathrm{J}$ Pharmacol Exp Ther. 2013;344(2):34859. doi: 10.1124/jpet.112.197483.

10. Sahathevan R, Brodtmann A, Donnan GA. Dementia, stroke, and vascular risk factors: A review. Int J Stroke. 2012;7(1): 61-73. doi: 10.1111/j.1747-4949.2011.00731.x.

11. Dangour AD, Whitehouse PJ, Rafferty K, Mitchell SA, Smith L, Hawkesworth $\mathrm{S}$, et al. B-vitamins and fatty acids in the prevention and treatment of Alzheimer's disease and dementia: A systematic review. J Alzheimers Dis. 2010;22(1):205 -24. doi: 10.3233/JAD-2010-090940.

12. Ismail A, Handayany GN, Mukminin ATN. Pengaruh penggunaan obat piracetam dan citicoline terhadap stroke iskemik di Rumah Sakit Umum Daerah (RSUD) Haji Makassar. J Pharm Alauddin Makassar. 2017;5(1):52-9.

13. Abdillah R, Armenia, Anggadireja K. Dampak terapi sitikolin, sosiodemografi dan komorbiditas terhadap nilai GCS pasien stroke di RSUP dr. M. Djamil Padang. J Sains Teknol Farm. 2017;19(1):s89-95.

14. SPS3 Investigators, Benavente OR, Hart RG, McClure LA, Szychowski JM, Coffey CS, Pearce LA. Effects of clopidogrel added to aspirin in patients with recent lacunar stroke. N Engl J Med. 2012;367(9):81725. doi: 10.1056/NEJM oa1204133.

15. Hoorn EJ. Intravenous fluids: Balancing solutions. J Nephrol. 2017;30(4):485-92. doi: 10.1007/s40620-016-0363-9.

16. Seo H, Jun IG, Ha TY, Hwang S, Lee SG, Kim YK. High stroke volume variation method by mannitol administration can decrease blood loss during donor hepatectomy. Medicine (Baltimore). 2016; 95(2):e2328. doi: 10.1097/MD.00000000 00002328. 